\title{
Effect of Bitumen on the Mechanical Properties of Medium Carbon Steel
}

\author{
Abdulmumin Akoredeley Alabi ${ }^{1 *}$, Peter Bitrus Madakson ${ }^{1}$, Danjuma Saleh Yawas $^{1}$, Terver Ause ${ }^{2}$ \\ ${ }^{1}$ Department of Mechanical Engineering, Faculty of Engineering, \\ Ahmadu Bello University, Zaria, Nigeria \\ ${ }^{2}$ Department of Metallurgical and Material Engineering, Faculty of Engineering, \\ Ahmadu Bello University, Zaria, Nigeria \\ Email: *aaalabi@abu.edu.ng
}

Received April 9, 2013; revised May 13, 2013; accepted May 22, 2013

Copyright (c) 2013 Abdulmumin Akoredeley Alabi et al. This is an open access article distributed under the Creative Commons Attribution License, which permits unrestricted use, distribution, and reproduction in any medium, provided the original work is properly cited.

\begin{abstract}
The effect of austempering of $0.45 \%$ carbon steel in hot bitumen on the hardness, impact strength, tensile properties and microstructure were investigated. The hardness values, impact strengths and tensile strengths of the austempered samples increased almost linearly from the austempering time of 1 hour to 3 hours after which they all dropped. At the austempering time of 3 hours the maximum values of hardness, impact strength and tensile strength of $496.2 \mathrm{HV}, 149 \mathrm{~J}$ and $706.2 \mathrm{~N} / \mathrm{mm}^{2}$ respectively were attained. These values are $24.5 \%, 4.9 \%$ and $25.8 \%$ higher than the hardness values, impact strength and tensile strength respectively of the as-received steel. The high impact strength and tensile strength recorded despite the high hardness value was probably due to the formation of bainite structure and the diffusion of carbon from the bitumen into the steel samples.
\end{abstract}

Keywords: Bitumen; Austempering; Mechanical Properties; Tensile Strength; Impact Strength

\section{Introduction}

Heat Treatment is the controlled heating and cooling of metals to alter their physical and mechanical properties without changing the product shape. Heat treatment is sometimes done inadvertently due to manufacturing processes that either heat or cool the metal such as welding or forming [1]. The working environment of a material could also expose it to some form of alternating heating and cooling conditions. Pipes and storage tanks used in handling of refined petroleum products are typical examples. Bitumen is also an example of material usually handled in the hot state. It can only flow, and mix properly with gravels in the molten state. Bitumen is a fossil fuel, which occurs naturally on its own or as a by-product of vacuum distillation of crude oil [2]. It is also referred to as a viscous liquid, or a solid consisting essentially of hydrocarbons and their derivatives, and is soluble in carbon disulphide, substantially non-volatile and softens gradually when heated. It is blackish or brownish in colour and possesses water proofing and ad-

${ }^{*}$ Corresponding author. hesive properties [3]. Just like refined petroleum products bitumen is usually transported via steel pipes. In the construction industries, most equipment used for handling bitumen are made from steel. Therefore it is imperative to understand the effect of hot bitumen on the mechanical properties of steels.

The effect of different media on the properties of steel has been studies. Water is probably the most notable of all. Water quenching of steel can be described as the rapid cooling of steel from the solution treating temperature, usually in the range of $845^{\circ} \mathrm{C}$ to $870^{\circ} \mathrm{C}$. Quenching is usually performed in order to prevent ferrite or pearlite precipitation and facilitate the formation of martensite or bainite [4]. In the hardened condition, steel should have $100 \%$ martensite to attain maximum yield strength [5]. The severity of water makes the hardened steels brittle and in some cases developed internal cracks thus limiting their engineering application. These shortcomings of water quenched steels have almost made the phrase "water quenched and tempered" a form of heat treatment, since all water quenched steel are tempered. With tempering, the properties of quench steel could be modified to decrease hardness and increase ductility and impact 
strength [5]. Another way to minimized distortion in dimensions and cracking during quenching was to minimize the temperature differences between different areas of a part (or sample). This often requires the use of oil or aqueous polymer solutions to moderate the heat transferred during quenching [4]. Researchers have shown that mineral and vegetable oils could compete favorably with water as steel quenchant producing similar hardness with higher impact strength [6]. Neem seed oil and engine oil have also been proven to be good quenchants for plain carbon steel and ductile cast iron. They gave hardness values close to those of water quenched samples while their impact strength were higher [7].

According to Adewuyi and Afonja [8] and Raymond [9], austempering is one of the isothermal heat treatment methods used for hardening of ferrous metal. The austempering process consist of heating a ferrous component to a temperature between $825^{\circ} \mathrm{C}-950^{\circ} \mathrm{C}$, soaking at this temperature for 1 - 2 hours then quenching into a hot liquid medium maintained at a pre-selected temperature between $250^{\circ} \mathrm{C}-450^{\circ} \mathrm{C}$ then removed and cooled to room temperature in air.

Kazerooni et al. [10] used salt bath furnace and investigated the influence of austenitizing temperature of $950^{\circ} \mathrm{C}, 920^{\circ} \mathrm{C}, 870^{\circ} \mathrm{C}, 840^{\circ} \mathrm{C}$, and $800^{\circ} \mathrm{C}$ on austempering kinetics, austempered microstructure, mechanical properties and hardenability of $\mathrm{Mn}-\mathrm{Mo}-\mathrm{Cu}$ alloyed ductile iron. They found that decreasing the austenitizing temperature accelerates the introduction of ferrite into the austempered structure.

According to Adewuyi and Afonja [11], unalloyed ductile iron requires shorter austempering times in the range of 30 minutes - 4 hours. While alloyed ductile cast iron requires longer times. The alloying elements delay the austempering reactions.

This work is aimed at investigating the effect of bitumen austempering on the mechanical properties of medium carbon steel.

\section{Materials and Methods}

\subsection{Materials}

The materials used for this work include:

1) Steel sample: The steel sample was obtained from Delta Steel Rolling Mill. Table 1 show the composition of the steel sample.

2) Bitumen: The bitumen was obtained from Department of Civil Engineering, Ahmadu Bello University, Zaria.

3) Water: The water was collected from the public water supply system on Ahmadu Bello University, Zaria.

The equipment used include: Lathe machine, electric furnace, Vicker hardness Testing machine, Hounsfield balanced impact tester, Denison universal testing machine, digital image capturing microscope.
Table 1. Composition of steel sample (delta steel rolling mill, nigeria).

\begin{tabular}{cc}
\hline Element & Percentage by weight \\
\hline $\mathrm{C}$ & 0.45 \\
$\mathrm{Si}$ & 0.42 \\
$\mathrm{Mn}$ & 0.55 \\
$\mathrm{P}$ & 0.01 \\
$\mathrm{~S}$ & 0.002 \\
$\mathrm{Cu}$ & 0.14 \\
$\mathrm{Mo}$ & 0.008 \\
$\mathrm{Ni}$ & 0.002 \\
$\mathrm{Cr}$ & 0.14 \\
$\mathrm{Al}$ & 0.003 \\
$\mathrm{~T}$ & 0.008 \\
$\mathrm{Co}$ & 0.003 \\
$\mathrm{Sn}$ & 0.013 \\
$\mathrm{Fe}$ & 93.2 \\
\hline
\end{tabular}

\subsection{Methods}

\subsubsection{Sample Preparation}

Twenty-five samples were machined for each of the tensile test, impact test and hardness test. The dimension of the tensile test sample was $\phi 12 \mathrm{~mm} \times 140 \mathrm{~mm}$ with a gauge length of $50 \mathrm{~mm}$, that of the impact strength test was $\phi 11.45 \mathrm{~mm} \times 70 \mathrm{~mm}$ with a notch $2 \mathrm{~mm}$ deep, and that of the hardness test was $\phi 10 \mathrm{~mm} \times 10 \mathrm{~mm}$. The samples used for the hardness test were also used for the microstructural analysis.

\subsubsection{Quenching in Water and Tempering}

The samples were normalized after machining and divided into two batches. The results of the mechanical test carried out on the normalized samples are shown in Table 2. Each batch comprising ten samples each for tensile test, impact test and hardness test. The first batch was divided into two equal portions, put into different metallic containers and heated to $900^{\circ} \mathrm{C}$ for one hour in a furnace. The content of the containers was then quenched separately into two different reservoirs of 100 litres of water each. This volume of water is large enough to prevent a temperature rise of more than $1^{\circ} \mathrm{C}$.

Approximate volume of water required to quench one impact test sample is obtained using this relationship

$$
\begin{aligned}
& \mathrm{M}_{\mathrm{s} 1} \mathrm{C}_{\mathrm{s}}\left(\mathrm{T}_{1}-\mathrm{T}_{3}\right)=\mathrm{M}_{\mathrm{w} 1} \mathrm{C}_{\mathrm{w}}\left(\mathrm{T}_{3}-\mathrm{T}_{2}\right) \\
& 65 * 0.42 *(900-33)=\mathrm{M}_{\mathrm{w} 1} * 4.2 *(33-32) \\
& 23669.1=4.2 \mathrm{M}_{\mathrm{w} 1} \\
& \mathrm{M}_{\mathrm{w} 1}=5.64 \mathrm{~kg} \\
& \text { But volume = mass/density } \\
& \text { Using density of water as } 1 \mathrm{~g} \cdot \mathrm{cm}^{-3} \\
& \text { Hence, the volume of water needed is } 5.7 \text { litres }
\end{aligned}
$$


Table 2. Result of some mechanical tests carried out on the as-received, normalized and water quenched samples.

\begin{tabular}{cccc}
\hline & As-received & Normalized & $\begin{array}{c}\text { Water } \\
\text { quenched }\end{array}$ \\
\hline $\begin{array}{c}\text { Impact strength } \\
(\mathrm{J})\end{array}$ & 142 & 147 & 81 \\
$\begin{array}{c}\text { Hardness (HV) } \\
\text { Tensile strength } \\
\left(\mathrm{N} / \mathrm{mm}^{2}\right)\end{array}$ & 398.5 & 405.0 & 598.5 \\
$\begin{array}{c}\text { \% elongation } \\
\text { \% reduction in } \\
\text { area }\end{array}$ & 10.0 & 603.2 & 212 \\
\hline
\end{tabular}

Approximate volume of water required to quench one tensile test sample is obtained as follows:

$$
\begin{aligned}
& \mathrm{M}_{\mathrm{s} 2} \mathrm{C}_{\mathrm{s}}\left(\mathrm{T}_{1}-\mathrm{T}_{3}\right)=\mathrm{M}_{\mathrm{w} 2} \mathrm{C}_{\mathrm{w}}\left(\mathrm{T}_{3}-\mathrm{T}_{2}\right) \\
& 150 * 0.42 *(900-33)=\mathrm{M}_{\mathrm{w} 2} * 4.2 *(33-32) \\
& \mathrm{M}_{\mathrm{w} 2}=13.0 \mathrm{~kg} \\
& \text { But volume = mass/density } \\
& \text { Using density of water as } 1 \mathrm{~g} \cdot \mathrm{cm}^{-3} \\
& \text { Hence, the volume of water needed is } 13 \text { litres }
\end{aligned}
$$

Approximate volume of water required to quench one hardness test sample is obtained as follows:

$$
\begin{aligned}
& \mathrm{M}_{\mathrm{s} 3} \mathrm{C}_{\mathrm{s}}\left(\mathrm{T}_{1}-\mathrm{T}_{3}\right)=\mathrm{M}_{\mathrm{w} 3} \mathrm{C}_{\mathrm{w}}\left(\mathrm{T}_{3}-\mathrm{T}_{2}\right) \\
& 25 * 0.42 *(900-33)=\mathrm{M}_{\mathrm{w} 3} * 4.2 *(33-32) \\
& \mathrm{M}_{\mathrm{w} 3}=2.18 \mathrm{~kg}
\end{aligned}
$$

But volume $=$ mass $/$ density

Using density of water as $1 \mathrm{~g} \cdot \mathrm{cm}^{-3}$

Hence, the volume of water needed is 2.2 litres

The result of the various mechanical test carried out on the water quenched samples are shown on Table 2.

To reduce the stresses developed in the water quenched samples and also make them less brittle, the samples were tempered for one hour in pairs. A pair contained two impact test samples, two tensile test samples and two hardness test samples. Each pair was tempered for one hour at different temperature. The first set was tempered for one hour at $200^{\circ} \mathrm{C}$, the second set at $300^{\circ} \mathrm{C}$, the third set at $400^{\circ} \mathrm{C}$ and the fourth set at $500^{\circ} \mathrm{C}$. The results of the hardness test, impact test and tensile test carried out on the tempered samples are shown in Figure 1 to Figure 3.

\subsubsection{Austempering in Bitumen}

Four litres of stabilized bitumen was heated on a stove, in an aluminium pot, to a temperature of $290^{\circ} \mathrm{C}$.

To estimate the mass of the steel samples that can be safely austempered in the bitumen at a given time, the

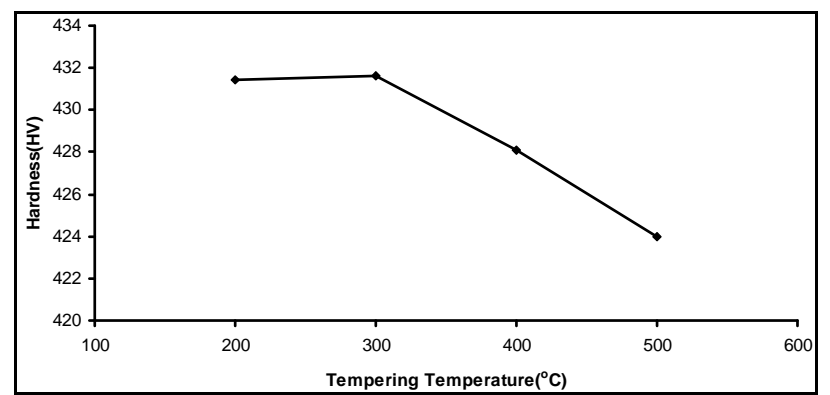

Figure 1. Effect of tempering temperatures on the hardness of steel samples quenched in water at room temperature.

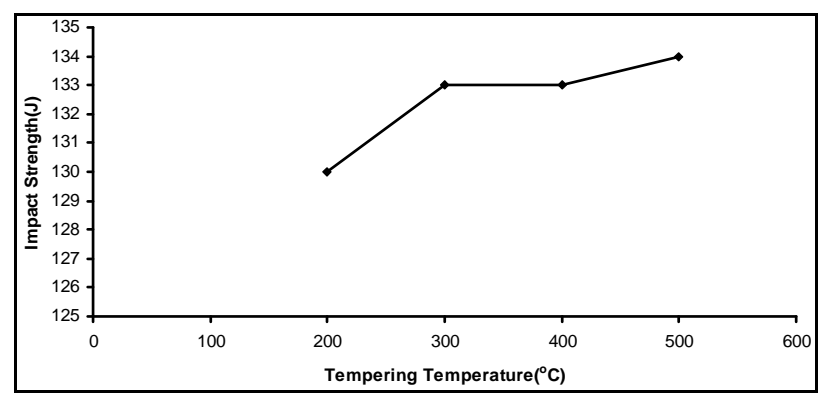

Figure 2. Effect of tempering temperatures on the impact strength on the samples quenched in water at room temperature.

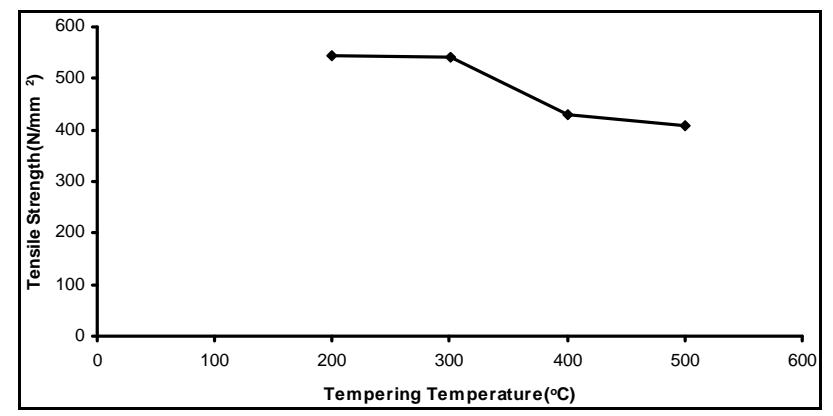

Figure 3. Effect of tempering temperatures on the tensile strength of the samples quenched in water.

following was considered [12]:

$$
\begin{aligned}
\text { Heat loss by steel } & =M_{\mathrm{s}} \mathrm{C}_{\mathrm{s}}\left(\mathrm{T}_{1}-\mathrm{T}_{5}\right) \\
& =\mathrm{M}_{\mathrm{s}} * 0.42 *(900-300) \\
& =252 \mathrm{M}_{\mathrm{s}} \mathrm{J}
\end{aligned}
$$

Heat gained by aluminium pot $=\mathrm{M}_{\mathrm{a}} \mathrm{C}_{\mathrm{a}}\left(\mathrm{T}_{5}-\mathrm{T}_{4}\right)$

$$
\begin{aligned}
& =400 * 0.9 *(300-290)(6) \\
& =3600 \mathrm{~J}
\end{aligned}
$$

Total heat gained $=156,000+3600$

$$
=159,600 \mathrm{~J}
$$


Assuming that no heat is lost to the surroundings, from first law of thermodynamics [13],

$$
\begin{aligned}
& \text { Heat lost by steel = Total heat gained } \\
& 252 M_{s}=159,600 \\
& M_{s}=633.33 \mathrm{~g}
\end{aligned}
$$

The above analysis shows that $633.33 \mathrm{~g}$ of steel at $900^{\circ} \mathrm{C}$ is needed to cause the temperature of 4 litres of the bitumen to rise from $290^{\circ} \mathrm{C}$ to $300^{\circ} \mathrm{C}$. At no time during the experiment was the total mass of steel samples in the bitumen more than $300 \mathrm{~g}$.

From the samples normalized, ten impact test samples, ten tensile test samples and ten hardness test samples were austempered in pairs. A pair comprised one impact test samples, one tensile test sample and one hardness test sample. A pair was put in the steel container and placed in the electric furnace. It was heated to $900^{\circ} \mathrm{C}$ and soaked at this temperature for one hour. The container with the content was then removed from the furnace and carefully quenched (emptied) into the bitumen boiling on the stove at $290^{\circ} \mathrm{C}$. After one hour, all the samples were removed from the bitumen and allowed to cool in air to room temperature. This procedure was repeated for four other pairs that were quenched in the bitumen for 2 hours, 3 hours, 4 hours and 5 hours respectively. All the samples austempered in bitumen were later cleaned using kerosene to remove bitumen that might be left on their surfaces. The result of the hardness test, impact test and tensile test carried out on the austempered samples are shown in Figure 4 to Figure 6.

For every heat treatment operation carried out one hardness test sample was prepared for optical microscopic investigation. With water as lubricant and coolant, the hardness test samples were grinded with silicon carbide abrasive papers of grades 240,320, 400, and 600 grit sizes, polished using chronic oxide polishing powder and etched with $2 \%$ Nital solution.

\section{Results and Discussion}

The result in Table 2 showed that the normalized samples had an increment of 3.3\% in impact strength, $4.0 \%$ in hardness value, $7.4 \%$ in tensile strength, $4.0 \%$ in percentage elongation and $6.0 \%$ in percentage reduction in area over the as-received sample. It can be inferred that normalization made the medium carbon steel more ductile and tougher. This is due to the refining of the grain sizes and eliminating precipitate of carbide network at the austenite grain boundary of the as-received steel, as shown in Plates 1 and 2. This agrees with the findings of Thelning [14] and Alabi [12].

Table 2 also showed the water quenched samples had the lowest impact strength, $81 \mathrm{~J}$. This value is over $75 \%$ lower than the value of the impact strength for either the

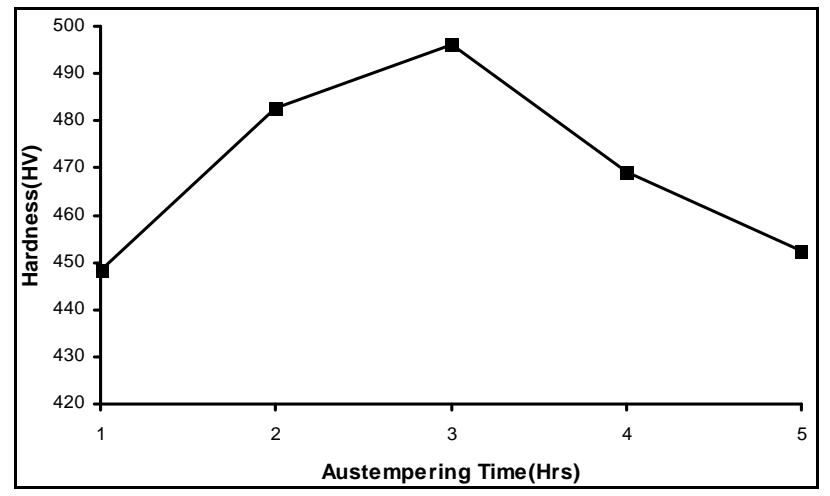

Figure 4. Effect of austempering time on the hardness value of the samples austempered in hot bitumen bath at $290^{\circ} \mathrm{C}$.

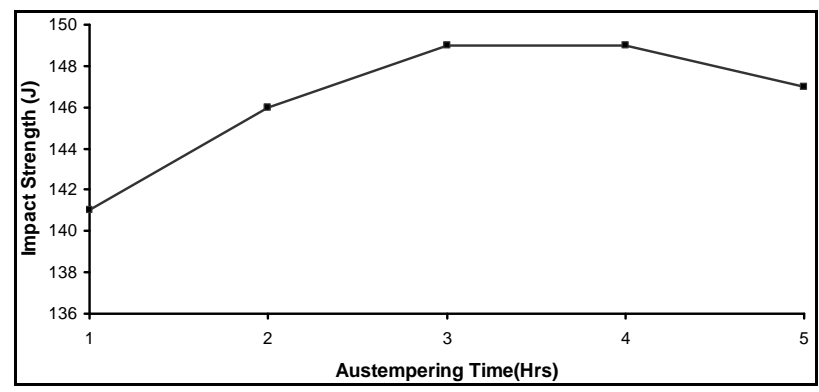

Figure 5. Effect of austempering time on the impact energy of the samples austempered in hot bitumen bath at $290^{\circ} \mathrm{C}$.

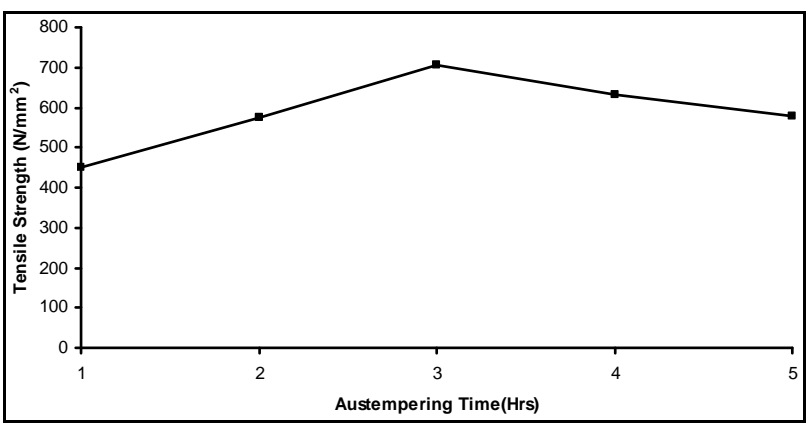

Figure 6. Effect of austempering time on the tensile strength of samples austempered in hot bitumen bath at $290^{\circ} \mathrm{C}$.

as-received or normalized sample. This drastic drop in impact strength was due to the formation of hard martensite in the structure of the steel during water quenching.

On the other hand, the hardness value of the water quenched samples appreciated remarkably when compared with the hardness value of the as-received and the normalized samples. The $598.5 \mathrm{HV}$ recorded for the water quenched sample is higher than the hardness value for each of the as-received and the normalized by over $47 \%$. This is also due to the formation of the hard martensite in the steel structure and the very hard steel case formed due to high severity of quench of water. This is in agreement with Kempster [11] who stated that water should be used if plain carbon steel is to have a high value of 


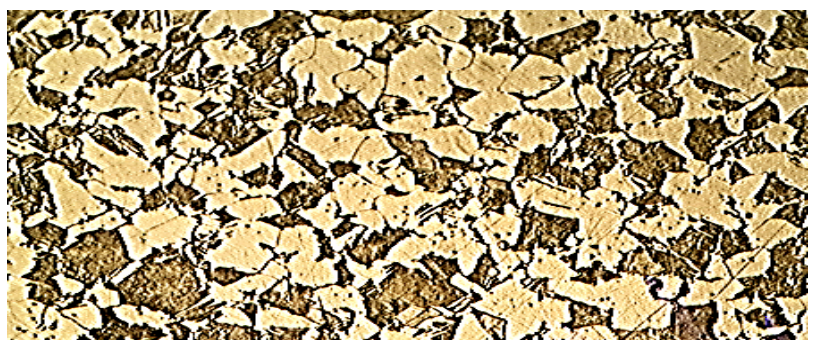

Plate 1. Microstructure of as-received steel sample showing pearlite (dark) in the matrix of ferrite (white). Etchant: $2 \%$ Nital. $\times 400$.

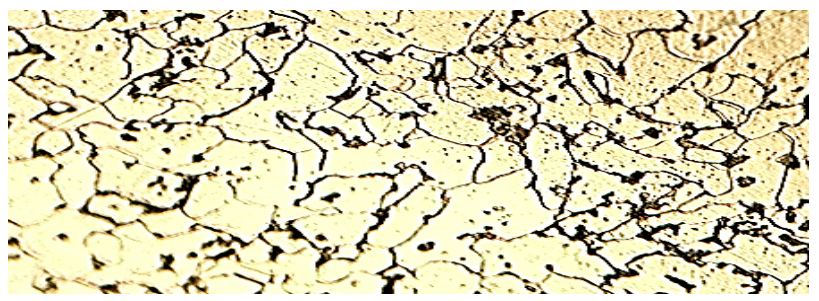

Plate 2. Microstructure of normalized sample showing pearlite in the ferrite matrix. Etchant: $\mathbf{2 \%}$ Nital. $\times \mathbf{4 0 0}$.

hardness.

The tensile strength, percentage elongation and percentage reduction in area of the water quenched samples are the least when compared with the results of samples subjected to the other heat treatment processes. This is due to the formation of hard martensite structure in the steel, as shown in Plate 3, and the formation of hard case around the steel which made the water quenched samples the most brittle. This is in agreement with Raymond [9] who stated that water quenching of steel containing sufficient amount of carbon produces an extremely hard structure called martensite which appears under the microscope as a mass of needle-shaped crystals.

The results in Figure 1 shows that the tempering heat treatment cause a significant decrease in the hardness value of medium carbon steel as the tempering temperature increased from $200^{\circ} \mathrm{C}$ to $500^{\circ} \mathrm{C}$. This is due to the fact that the hard martensitic structure of the water quenched steel was transformed into tempered martensite, a ferrite-cementite matrix, during the tempering operation as shown in Plates 3 to 6. This is in agreement with the Rajan et al. [1] and Raymond [9] who stated that the higher the tempering temperature the more closely will the original martensite structure revert to ferrite-cementite mixture and so strength and hardness fall progressively, while toughness and ductility increase.

There was no significant rise in the impact strength of the steel as the tempering temperature rose as shown in Figure 2. But the lowest of the impact strength, $130 \mathrm{~J}$, which occur at $200^{\circ} \mathrm{C}$, is $60 \%$ higher than the impact strength of the water quenched samples. The tempered martensite structure gave the tempered medium carbon

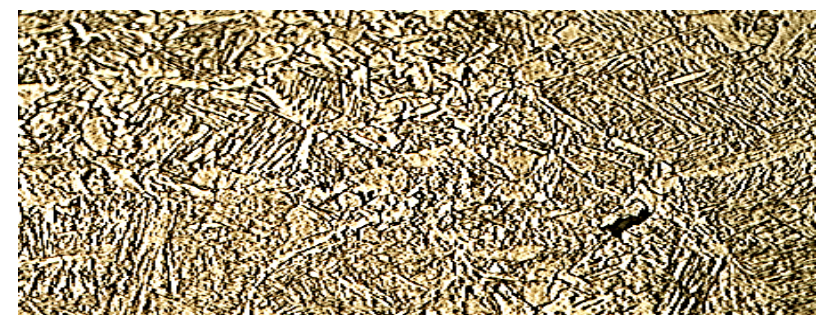

Plate 3. Microstructure of a water quenched sample showing martensite. Etchant: $\mathbf{2 \%}$ Nital. $\times \mathbf{4 0 0}$.

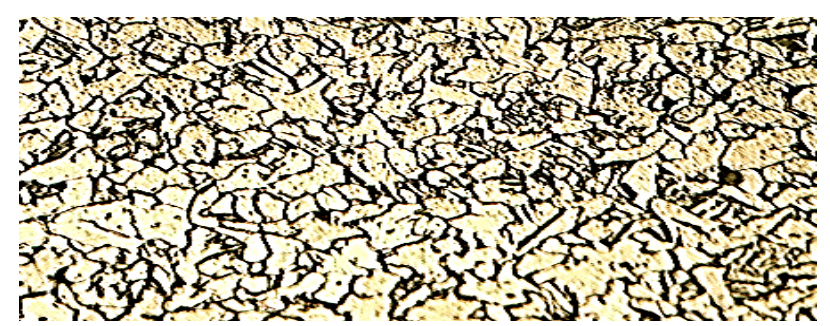

Plate 4. Microstructure of a sample of the carbon steel tempered at $200^{\circ} \mathrm{C}$ for 1 hour showing tempered martensite. Etchant: $2 \%$ Nital. $\times 400$.

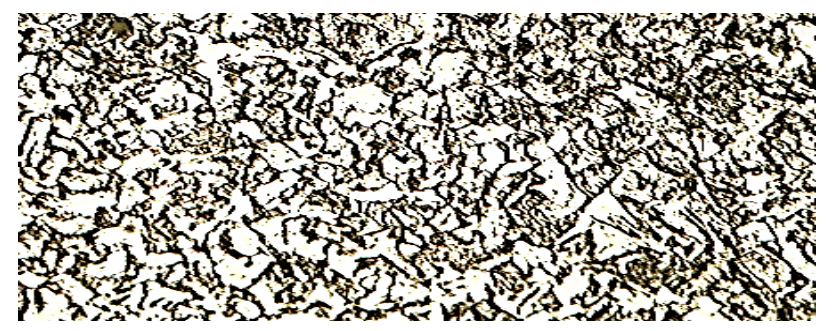

Plate 5. Microstructure of a sample of the carbon steel tempered at $300^{\circ} \mathrm{C}$ for 1 hour showing tempered martensite. Etchant: $2 \%$ Nital. $\times 400$.

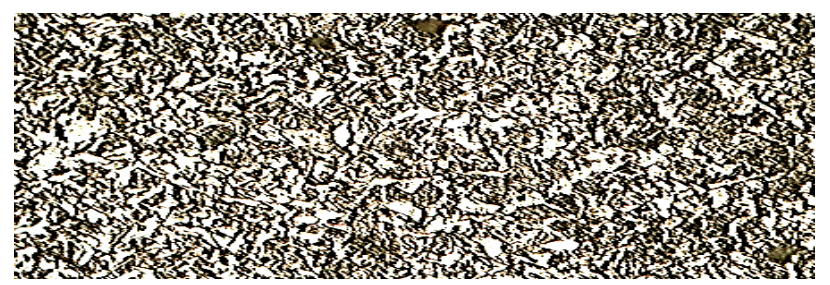

Plate 6. Microstructure of a sample of the carbon steel tempered at $400^{\circ} \mathrm{C}$ for 1 hour showing tempered martensite. Etchant: $2 \%$ Nital. $\times \mathbf{4 0 0}$.

steel an improved toughness and improved ductility.

The result in Figure $\mathbf{3}$ show that the tensile strength of the tempered steel samples fall steadily as the tempering temperature increased from $200^{\circ} \mathrm{C}$ to $500^{\circ} \mathrm{C}$.

Figure 4 is the graphical representation of the variation of the samples' hardness with the austempering time. The hardness values of the samples increase from an austempering time of 1 hour and attain a maximum value of 496.2 HV after 3 hours. This significant rise in hardness could be due to the increment recorded in the carbon 
content of the samples after austempering. This rise in carbon content might have been as a result of diffusion of carbon from hot bitumen into the samples. The hardness then dropped progressively from the maximum value at 3 hours to $452.4 \mathrm{HV}$ after 5 hours. This is due to tempering of the structure of the axle as it stays in the bitumen for more than 3 hours.

Figure 5 show the graphical variation of the impact strength of the samples austempered in bitumen at $290^{\circ} \mathrm{C}$ with the austempering time. The impact strength increased significantly from the austempering time of 1 hour and attains a maximum value of $149 \mathrm{~J}$ after 3 hours. This increment may be due to the formation of bainite structure and some retained austenite in the sample, as shown in Plates $\mathbf{7}$ to 11. This is in agreement with Ause [15] and Alabi [16] who stated that this increase could be as a result of formation of bainite structure during the austempering heat treatment. There was no significant change in the impact strength from austempering time of 3 hours to 5 hours.

Figure 6 depicts the variation of tensile strength of samples with different austempering time. There was a significant rise in tensile strength from austempering time of 1 hour to 3 hours. At 3 hours the maximum tensile strength of $706.2 \mathrm{~N} / \mathrm{mm}^{2}$ was attained. This increment in tensile strength is likely due to formation of bainite structure in the samples. Figure 7 shows graphically the variation of percentage elongation and percentage reduction in area of samples with different austempering time. There was a rise in both percentage elongation and percentage reduction in area of samples as austempering time rose from 1 hour to 3 hours. The highest value of $42.0 \%$ for percentage elongation and $74.7 \%$ for percentage reduction in area were recorded at the austempering time of 3 hours. From 3 hours to 4 hours, both experience a slight drop in values and maintained almost the same value for the next hour. From the above, it can be inferred that austempering made the steel tougher and more ductile. This in agreement with Rajan et al. [1] who stated that austempering, as compared to conventional hardening and tempering treatment, results in better ductility at high hardness levels, improved impact and fatigue strength and freedom from distortion.

\section{Conclusions}

From the results of this work, the following conclusions can be drawn:

1) The steel sample responded well to heat treatment. This is evident in the improved mechanical properties achieved in the heat treated samples over the as-received.

2) After 3 hours of austempering in hot bitumen at $290^{\circ} \mathrm{C}$ the optimum mechanical properties was attained. At this condition, the maximum impact strength, tensile

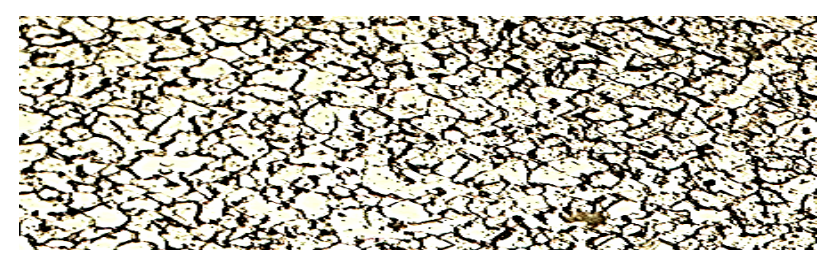

Plate 7. Microstructure of a sample austempered in hot bitumen at $290^{\circ} \mathrm{C}$ for 1 hour showing a mixture of retained austenite and pearlite. Etchant: $2 \%$ Nital. $\times 400$.

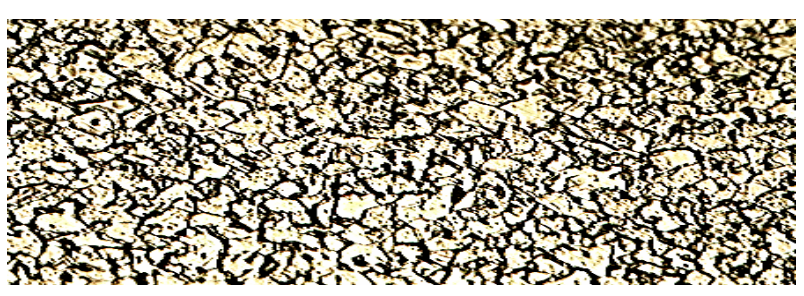

Plate 8. Microstructure of a sample austempered in hot bitumen at $290^{\circ} \mathrm{c}$ for 2 hour showing a mixture of bainite (precipitates of cementite in ferrite) and retained austenite. Etchant: $2 \%$ Nital. $\times \mathbf{4 0 0}$.

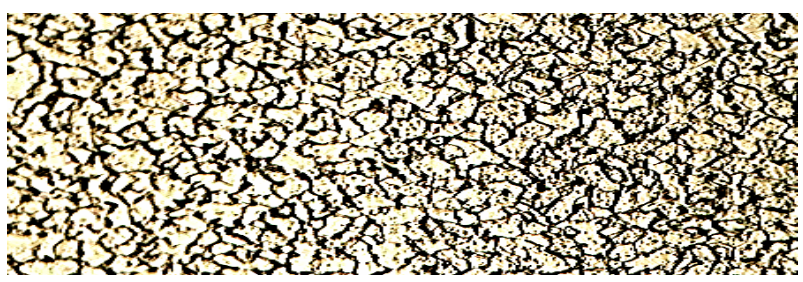

Plate 9. Microstructure of a sample austempered in hot bitumen at $290^{\circ} \mathrm{C}$ for 3 hour showing a mixture of bainite (precipitates of cementite in ferrite) and retained austenite. Etchant: $2 \%$ Nital. $\times \mathbf{4 0 0}$.

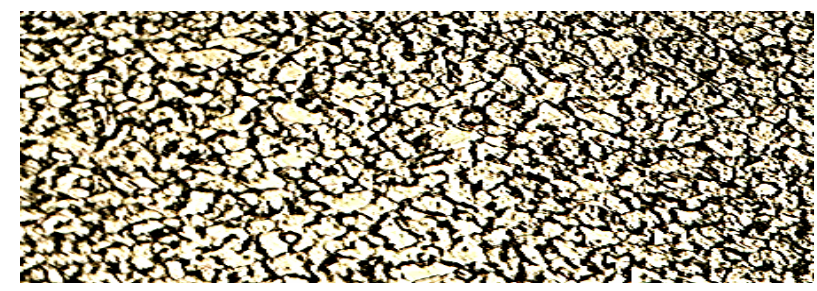

Plate 10. Microstructure of a sample austempered in hot bitumen at $290^{\circ} \mathrm{c}$ for 4 hour showing a mixture of bainite (precipitates of cementite in ferrite) and retained austenite. Etchant: $2 \%$ Nital. $\times \mathbf{4 0 0}$.

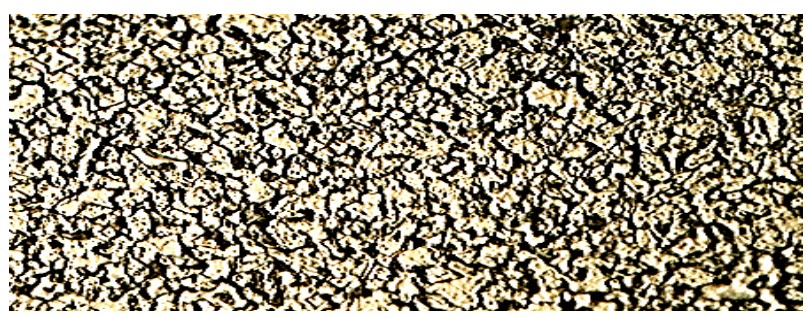

Plate 11. Microstructure of a sample of the carbon steel austempered in hot bitumen at $290^{\circ} \mathrm{C}$ for 5 hour showing a mixture of bainite (precipitates of cementite in ferrite) and retained austenite. Etchant: $\mathbf{2 \%}$ Nital. $\times \mathbf{4 0 0}$. 


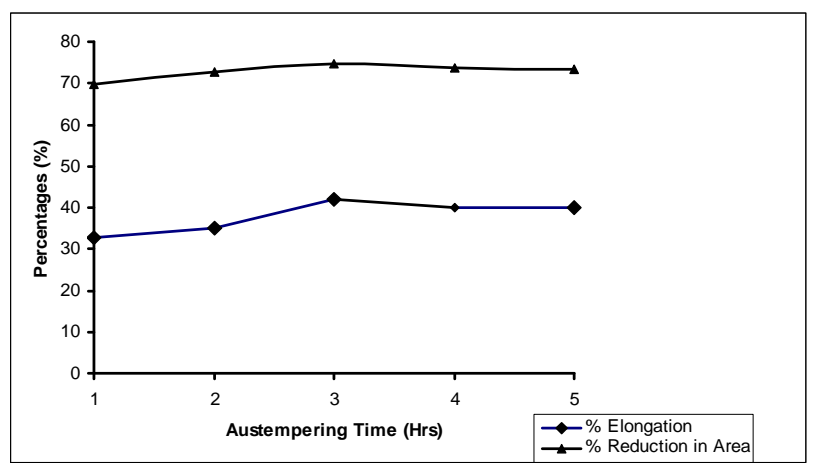

Figure 7. Effect of austempering time on the elongation (\%) and reduction in area $(\%)$ of samples austempered in hot bitumen bath at $290^{\circ} \mathrm{C}$.

strength, percentage elongation and percentage reduction in area of $149 \mathrm{~J}, 706 \mathrm{~N} / \mathrm{mm}^{2}, 42.0 \%$ and $74.7 \%$ respectively was recorded. And a hardness value of $496.0 \mathrm{HV}$ only second to the hardness value of the water quenched sample.

\section{REFERENCES}

[1] T. V. Rajan, C. P. Sharma and A. Sharma, "Heat Treatment Principle and Techniques,” Prentice-Hall, New Delhi, 1988, pp. 1-11.

[2] M. A. Olutoye, "Improvement of Nigeria Crude Residue,” Leonardo Journal of Science, No. 7, 2005, pp. 3342.

[3] Ips-M-Tp-295 Standard, "Material and Equipment Standard for Bitumen Primer (Cold Applied) for Use with Hot Applied Bitumen Enamel,” Iranian Ministry of Petroleum, July 1994. http://igs.nigc.ir/STANDS/IPS/M-TP-285.PDF

[4] C. E. Bates and G. E. Totten, "Quench Severity Effects on the As-Quenched Hardness of Selected Alloy Steels," Heat Treatment of Metals, Vol. 2, 1992, pp. 45-48.

[5] M. S. Htun, S. T. Kyaw and K. T. Lwin, "Effect of Heat Treatment on Microstructures and Mechanical Properties of Spring Steel," Journal of Metals, Materials and Minerals, Vol. 18, No. 2, 2008, pp. 191-197.

\section{List of Symbols}

$\mathbf{M}_{\mathrm{s} 1}=$ Mass of an impact test sample;

$\mathrm{M}_{\mathrm{s} 2}=$ Mass of a tensile test sample;

$\mathrm{M}_{\mathrm{s} 3}=$ Mass of a hardness test sample;

$\mathrm{M}_{\mathrm{w}}=$ Mass of water required for quenching operation;

$\mathrm{C}_{\mathrm{s}}=$ Specific heat capacity of steel;

$\mathrm{C}_{\mathrm{w}}=$ Specific heat capacity of water;

$\mathrm{T}_{1}=$ Temperature of steel samples from furnace;

$\mathrm{T}_{2}=$ Initial Temperature of water;

$\mathrm{T}_{3}=$ Final temperature of water and steel mixture;

$\mathrm{M}_{\mathrm{b}}=$ Mass of bitumen used;
[6] M. B. Ndaliman, “An Assessment of Mechanical Properties of Medium Carbon Steel under Different Quenching Medium,” AU Journal of Technology, Vol. 10, No. 2, 2006, pp. 100-104.

http://www.journal.au.edu/au_techno/2006/oct06/journal TechV10N2_aticle06.pdf

[7] S. B. Hassan, J. B. Agboola, V. S. Aigbodion and E. J. Williams, "Hardening Characteristics of Plain Carbon Steel and Ductile Cast Iron Nsing Neem Oil as Quenchant," Journal of Minerals and Eaterials Characterization and Engineering, Vol. 10, No. 2, 2011, pp. 161-172.

[8] B. O. Adewuyi and A. A. Afonja, "Austempered Ductile Iron a Viable Alternative to Steel," Nigerian Journal of Engineering and Management, Vol. 1, No. 1, 2000, pp. 6-13.

[9] A. H. Raymand, "Engineering Metallurgy," 6th Edition, Part II, Edward Arnold, London, 1993.

[10] R. Kazerooni, N. Nazarboland and R. Elliott, "Use of Austempering Temperature in Control of Austempering of Mn-Mo-Cu Alloyed Ductile Iron,” Material Science and Technology, Vol. 13, No. 12, 1997, pp. 1007-1015. doi:10.1179/026708397790301990

[11] M. H. A. Kempster, "Material for Metallurgists,” ELBS, Hodder and Stoughton, 1984, pp. 16-24.

[12] A. A. Alabi, A. I. Obi, D. S. Yawas, I. A. Samotu and S. I. M. Stephen, "Effect of Water Temperature on the Mechanical Properties of Water-Quenched Medium Carbon Steel,” Journal for Energy Technologies and Policy, Vol. 2, No. 4, 2012, pp. 40-45.

[13] T. D. Eastop and A. McConkey, "Applied Thermodynamics for Engineering Technologies,” Longman Group, UK Ltd., 1993.

[14] K. E. Thelning, "Steel and Its Treatment," Butterworths, London, 1984.

[15] T. Ause, "Evaluation of Hot Bitumen Bath as a Quenching Medium for Austempering of Steels and Ductile Cast Iron,” Ph.D. Thesis, Ahmadu Bello University, Zaria, 2007.

[16] A. A. Alabi, "Improving the Mechanical Properties of Bicycle Axle Using Bitumen Treatment,” M.Sc. Thesis, Ahmadu Bello University, Zaria, 2009.

$\mathrm{M}_{\mathrm{a}}=$ Mass of aluminium pot;

$\mathrm{C}_{\mathrm{a}}=$ Specific heat capacity of Aluminium;

Specific gravity of bitumen $=1.0 \mathrm{~g} / \mathrm{cm}^{3}$;

$\mathrm{C}_{\mathrm{b}}=$ Specific heat capacity of bitumen;

$\mathrm{T}_{4}=$ Initial temperature of bitumen and Initial temperature of aluminium pot;

$\mathrm{T}_{5}=$ Final temperature of bitumen and steel mixture;

$\mathrm{M}_{\mathrm{s}}=$ Mass of steel that can be austempered. 